\title{
Progam Kemitraan Masyarakat (PKM) pada Kelompok Usaha Pembuatan Teh Daun Kahumama Berkhasiat Obat di Desa Ondo-Ondolu Kecamatan Batui, Banggai, Sulawesi Tengah
}

\author{
Bahidin Laode Mpapa ${ }^{1}$, Haruni Ode ${ }^{2}$ \\ 1,2 Universitas Muhammadiyah Luwuk Banggai
}

\begin{tabular}{l}
\hline Article History \\
\hline Received 10.09 .2019 \\
Received in revised form \\
08.11 .2019 \\
Accepted 04.12 .2019 \\
Available online 16.12 .2019
\end{tabular}

\begin{abstract}
COMMUNITY PARTNERSHIP PROGRAM IN THE BUSINESS GROUP FOR MAKING DRINK KAHUMAMA LEAVES FOR HERBAL IN ONDO-ONDOLU VILLAGE, BATUI DISTRICT, BANGGAI, CENTRAL SULAWESI. The wood of Kahumama includes a lot of local wood in the village of Ondo-Ondolu Batui subdistrict. Partners have the potential to utilize the parts of the kahumama trees such as leaves, to be a product that is worth selling. The potential of leaf raw material is abundant. Suitable business opportunity to utilize the leaves of the Kahumama is a drink efficacious medicine. There are three main problems of the partner, namely: not yet know the process of processing production of kahumama leaves into a tea efficacious medicine; Not yet know the ongoing business and marketing management as well; Not able to overcome the existence of people who still do wood theft in the working area of forest farmer groups. To solve the problem of partners given solutions in the form of training processing production process of Kahumama tea leaves that include: raw material selection techniques, trade, ministry, winding, drying and packaging; Business management and marketing training; and educating people about forests that include forest outcomes, forest cultivation and forest benefits from ecological, social and economic aspects. Community Partnership Program of the business group of the tea making leaves Kahumama efficacious drug implemented for one year in the village Ondo-Ondolu Batui District Banggai. The stages of this program are: observation, production process training of tea processing leaves, business management and marketing training as well as the importance of preserving forests, forest products, forest cultivation and the benefits of forests (ecology, social and Economic development). The result of this community service is farmer group Skills increased in the processing and production of herbal drink Kahumama leaves, thus the welfare of the community increases.
\end{abstract}

KEYWORDS: Business Group, Herbal, Leaf Kahumama. Attribution 4.0 International License, which permits unrestricted use, distribution, and reproduction in any medium, provided the original work is properly cited. C 2019 Bahidin Laode Mpapa, Haruni Ode.

\footnotetext{
${ }^{1}$ Corresponding author: Program Studi Agroteknologi, Fakultas Pertanian Universitas Muhammadiyah Luwuk Banggai ; Jl. KH. Ahmad Dahlan No.79, Luwuk. Email: bahidin@gmail.com
} 


\section{PENDAHULUAN}

Perkembangan penduduk Kabupaten Banggai berdasarkan proyeksi penduduk tahun 2016 sebanyak 360.0022 jiwa yang terdiri dari 183.299 jiwa penduduk laki-laki dan 176.723 jiwa penduduk perempuan. Jumlah penduduk Kabupaten Banggai mengalami pertumbuhan sebesar 3,31 persen. Jumlah tersebut tersebar di 23 kecamatan, 46 kelurahan dan 291 desa. Kabupaten Banggai memiliki luas wilayah sebesar 9.672,70 km². Kecamatan Nuhon dan Kecamatan Batui merupakan dua kecamatan, yang memiliki wilayah paling luas di Kabupaten Banggai (BPS Banggai, 2017).

Kecamatan Batui memiliki luas wilayah 1.062,36 km² dengan 13 Desa Desa. Desa Ondo-ondolu merupakan salah satu desa terluas luas di Kecamatan Batui dengan luas wilayah 65,32 km². Jarak Desa Ondo-Ondolu ke ibukota kecamatan $18 \mathrm{~km}$, sedangkan jarak ke ibukota Kabupaten $72 \mathrm{~km}$. Desa ini berada pada ketinggian $37 \mathrm{mdpl}$ dengan komposisi topografi berupa dataran $20 \%$, perbukitan $35 \%$ dan pegunungan $45 \%$. Desa Ondo-Ondolu masuk dalam klasifikasi desa swakarya. Sumber penghasilan penduduk mayoritas berasal dari pertanian tanaman pangan dan perkebunan dengan komoditas unggulan padi, kakao dan tanaman hortikultura. Lebih rinci dijelaskan bahwa banyaknya rumah tangga pertanian di desa ondo-ondolu untuk padi/palawija (180 kk), hortikultura (184 kk), perkebunan (249 kk), peternakan (117 kk) dan kehutanan (108 kk).

Penduduk Desa Ondo-ondolu sebagian masih bergantung pada hutan, terdapat 108 kepala keluarga yang masih bersentuhan langsung dengan hasil hutan baik kayu dan non kayu. Beberapa kepala keluarga tersebut, sebagian tergabung dalam kelompok tani hutan yang sengaja dibentuk untuk mendukung program pemerintah dalam pelestarian hutan. Salah satu kelompok tani hutan yang memiliki peran besar dalam menjaga kelestarian hutan di kecamatan Batui yaitu Kelompok Tani Hutan (KTH) Kahumama.

Berdasarkan letak geografisnya, KTH Kahumama berada pada koordinat 122025'7.673" BT dan 1012'59.753" LS. KTH ini dibentuk pada tahun 2017 dan mengelola lahan hutan dengan luas kurang lebih 100 ha. Salah satu tanaman kehutanan yang banyak di kelola oleh kelompok ini yaitu kayu jabon atau dalam bahasa lokal disebut dengan kayu kahumama. Kayu kahumama/jabon terdiri dari jabon merah dan jabon putih. Jabon putih (Anthocephalus cadamba Miq., syn. A. chinensis Lamk. A. Rich. Ex Walp.) merupakan jenis tumbuhan asli dari Asia dan Asia Tenggara, tumbuh secara alami di India, China bagian selatan, hingga Australia (Jansen et al, 1993; Orwa et al.,2009). Sebaran asli jabon merah (Anthocephalus macrophyllus (Roxb.) Havil) terbatas di Sulawesi dan pulau-pulau di Maluku (Fox, 1971). Dua jenis jabon ini mungkin dianggap sama, namun keduanya menunjukkan perbedaan penampilan maupun pertumbuhan dimana hal ini diakui oleh petani maupun rimbawan (Krisnawati, Kallio, \& Kanninen, 2011).

Kayu kahumama termasuk kayu lokal yang banyak tumbuh di Desa Ondo-ondolu Kecamatan Batui. Termasuk jenis cepat tumbuh (fast growing species) tersebar di Sulawesi dan Maluku (Jansen et al, 1993). Pertumbuhan riapnya tergolong cepat, bisa mencapai 5 cm per tahun (Mpapa, 2016), bisa dipanen dalam 5 tahun ketika diameter mencapai 30-40 cm (Mansur \& Tuhrteru, 2010).. Meskipun bersifat lokal, kayu ini telah digunakan sebagai bahan baku furnitur, pertukangan dan bahan bangunan. Bahkan kulit batangnya sudah dimanfaatkan sebagai obat pencahar oleh masyarakat Desa Lemo-lemo Halmahera Selatan dan/atau sebagai pengawet jaring ikan oleh masyarakat Desa Tulehu Kabupaten Maluku Tengah (Ohorella \& Ladjumat, 2009). Kahumama oleh masyarakat desa Ondo- 
Ondolu, banyak dimanfaatkan kayunya saja. Sementara daun, kulit dan ranting menjadi limbah yang tidak termanfaatkan.

Berdasarkan pengamatan di lapangan, mitra memiliki potensi untuk memanfaatkan bagian pohon kahumama seperti daun untuk dijadikan produk yang bernilai jual. Potensi bahan baku berupa daun sangat melimpah. Peluang usaha yang cocok untuk memanfaatkan daun pohon kahumama yaitu diolah menjadi minuman herbal berkhasiat obat. Minuman berkhasiat obat dari dedaunan sangat digemari oleh masyarakat pedesaan dan perkotaan, dikarenakan kandungannya sangat baik untuk kesehatan tubuh. Menurut Wali, Haneda, dan Maryana (2014) jabon merah berkhasiat sebagai obat karena mengandung senyawa fitokimia berupa kuinon dan steroid yang lebih banyak secara kualitatif dibandingkan jabon putih. Penelitian lain melaporkan kandungan ekstrak air daun jabon merah yaitu tanin, saponin, dan flavonoid (Khodijah, 2015). Sementara itu, ekstrak etanol daun jabon merah mengandung flavonoid, saponin, tanin, steroid, dan fenolik. (Lailiyah, 2016). Daun dan kulit kayu jabon merah dapat digunakan sebagai obat penambah stamina, mengurangi rasa lelah, menurunkan kolesterol dan penyubur kandungan. Daun jabon merah juga digunakan sebagai obat kumur (Halawane, Hidayah, \& Kinho, 2011).

Minuman herbal berkhasiat obat kebanyakan diolah dalam bentuk kering. Pada dasarnya ada tiga macam pengolahan teh yaitu teh hijau, pada pengolahannya tidak mengalami fermentasi, teh oolong yang pada pengolahannya mengalami fermentasi sebagian (semi ferementasi), dan teh hitam yang mengalami fermentasi penuh (anonim, 2008). Lebih lanjut menurut hambali dkk., (2005) bahwa teh herbal biasanya disajikan dalam bentuk kering seperti penyajian teh dari tanaman teh. Tanaman obat dalam bentuk kering yang diformulasikan menjadi herbal teh dapat dimanfaatkan untuk konsumsi sehari-hari oleh rumah tangga maupun industri. Pemanfaatan daun kahumama menjadi produk yang bernilai jual sangat dipengaruhi oleh faktor produksi dan manajemen. KTH kahumama selama kurang lebih setahun berdiri telah memiliki manajemen kelompok yang cukup baik. Ini terlihat dari adanya sekretariat, buku tamu dan struktur pengurus dalam kelompok. Namun terkait dengan pemanfaatan daun kahumama untuk minuman kesehatan, kelompok ini belum sama sekali memahami proses produksi dan pengolahannya. Serta bagaimana manajemen usaha dalam pemasarannya. Kondisi sumber daya manusia kth kahumama didominasi lulusan sekolah dasar dan menengah umum. Secara umum di desa ondo-ondolu tingkat pendidikan masih tergolong rendah. Hal ini pula yang menyebabkan masih kurangnya pemahaman masyarakat akan keberadaan hutan, sehingga tidak mengherankan masih sering terjadi pencurian kayu di wilayah ini.

Berdasarkan uraian di atas, program kemitraan masyarakat ini bertujuan untuk meningkatkan pengetahuan dan ketrampilan mitra dalam proses produksi pengolahan teh daun kahumama, manajemen usaha dan pemasaran produk serta semakin menguatkan kecintaan mitra dan warga Desa Ondo-Ondolu dalam menjaga ekosistem hutan.

\section{METODE PELAKSANAAN}

Program kemitraan masyarakat kelompok pembuatan teh daun kahumama berkhasiat obat, dilaksanakan selama setahun di Desa Ondo-Ondolu Kecamatan Batui 
Kabupaten Banggai Provinsi Sulawesi Tengah. Adapun tahapan program kemitraan masyarakat ini yaitu:

1) Pelatihan proses produksi pengolahan teh daun kahumama

Pelatihan proses produksi pengolahan teh daun kahumama dilakukan dalam bentuk ceramah dan praktek. Mitra diberikan materi mengenai alur proses produksi pengolahan teh daun kahumama meliputi; pemilihan bahan baku, perajangan, pelayuan, penggulungan, pengeringan, dan pengemasan. Proses pengolahannya mengikuti proses pengolahan teh yang dicontohkan oleh Supriyanto, Darmadji, dan Susanti (2014), teh daun dibuat dari dua macam daun, yaitu daun muda dan daun tua. Daun muda yaitu daun nomer 1 sampai dengan 4 yang dihitung dari pucuk daun dan daun tua yaitu daun nomer 5 sampai dengan nomer 8. Khusus untuk daun kahumama yang lebar, harus dirajang kecil-kecil agar mudah dalam proses selanjutnya. Kemudian Dilakukan pelayuan pada suhu $90-100^{\circ} \mathrm{C}, \mathrm{RH}<70 \%$ dengan tebal hamparan satu lapis. Daun layu digiling menggunakan alat penggling daging pada kecepatan putar alat $40 \mathrm{rpm}$ pada kondisi suhu ruang dan kelembaban ruang. Lama penggilingan/penggulungan tidak melebihi 30 menit. Bubuk daun hasil penggilingan/penggulungan dikeringkan dengan menggunakan cabinet drier pada suhu $90-100^{\circ} \mathrm{C}$ pada $\mathrm{RH}, 70 \%$ selama 4 jam. Bubuk daun yang telah kering kemudian dikemas dengan kemasan plastik atau kemasan celup.

\section{2) Pelatihan Manajemen Usaha dan Pemasaran}

Pelatihan manajemen usaha dan pemasaran dilakukan dalam bentuk ceramah dan diskusi. Mitra akan diberikan materi tentang manajemen usaha yang meliputi: tertib administrasi, kreativitas dan fokus. Untuk pemasaran, mitra akan diajarkan strategi pemasaran yang meliputi: melakukan STP (segmenting, targeting dan positioning), mutu produk, distribusi, penetapan harga, promosi, teknologi informasi dan persaingan produk (Firmansyah, 2015).

3) Penyuluhan Pentingnya Menjaga Hutan (Hasil Hutan, Budidaya Hutan dan Manfaat Hutan (Ekologi, Sosial dan Ekolomi).

Penyuluhan dilaksanakan dalam bentuk ceramah dan diskusi. Peserta penyuluhan selain dihadiri oleh mitra, juga akan dihadiri oleh aparat desa dan masyarakat Desa OndoOndolu. Materi penyuluhan meliputi hasil hutan baik kayu maupun non kayu, budidaya hutan dan manfaat hutan dari aspek ekologi, sosial dan ekonomi.

\section{HASIL DAN PEMBAHASAN}

\section{Pelatihan Proses Produksi Pengolahan Teh Daun Kahumama}

Pelatihan proses produksi pengolahan teh daun kahumama dilaksanakan selama sehari bertempat di sekretariat kelompok tani hutan (KTH) kahumama. Kegiatan ini dihadiri oleh pemateri (Bapak Bahidin Laode Mpapa, S.Hut., M.Sc), anggota KTH kahumama, penyuluh kesatuan pengelolaan hutan (KPH) Toili Baturube dan perwakilan mahasiswa. Kegiatan ini di awali dengan pemaparan materi tentang manfaat dan keunggulan tanaman jabon merah (kahumama) sebagai bahan baku utama pembuatan teh. Pada sesi ini, anggota kelompok yang keselurahan belum mengetahui manfaat daun kahumama sebagai bahan baku teh berkhasiat obat, memberikan respon yang positif untuk memproduksi teh daun kahumama setelah megetahui manfaat yang 
dikandungnya. Respon positif dari seluruh anggota KTH kahumama cukup beralasan, dikarenakan sumber bahan baku daun kahumama cukup melimpah di desa tempat mereka bermukim. Mitra diajarkan mengenai teknik pemilihan bahan baku yang tepat, perajangan, pembersihan bahan baku, pengeringan, penggilingan dan pengemasan. Setelah mendapatkan materi proses produksi pengolahan teh, anggota kelompok mempraktekan proses produksi pengolahan teh dari awal sampai menghasilkan produk teh yang telah dikemas (Gambar 1).

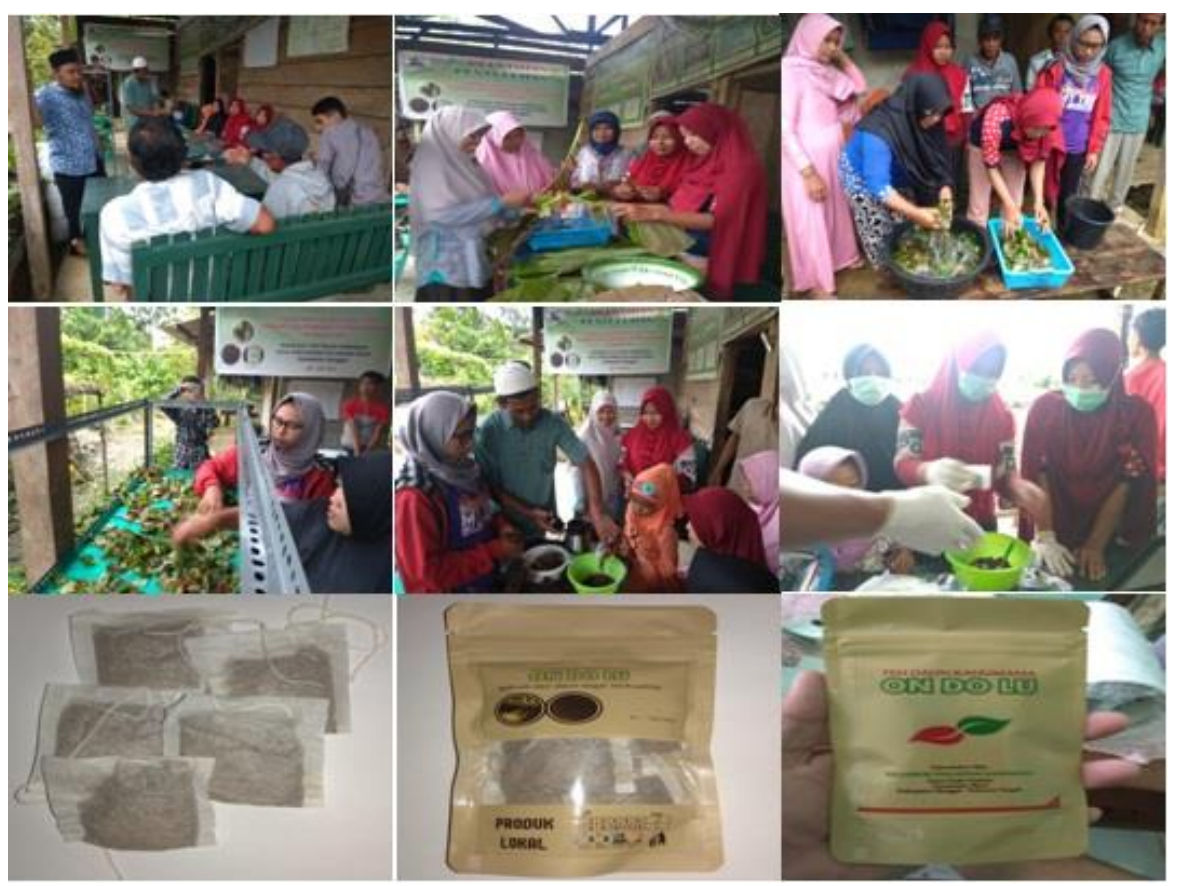

Gambar 1. Pelatihan Proses Produksi Pengolahan Teh Daun Kahumama

Dalam proses produksi pengolahan teh daun kahumama, KTH kahumama di beri penekanan agar dalam melakukan pengolahan teh senantiasa memperhatikan kebersihan dan mengikuti alur proses produksi, sehingga diperoleh produk yang berkualitas. Berdasarkan hasil pengujian laboratorium penelitian dan pengujian terpadu (LPPT) UGM tahun 2019, sampel teh daun kahumama memiliki kandungan kadar air (11,11 \%), Kadar abu (3,38\%), lemak total (0,10\%), serat kasar (59,41\%), protein (9,44\%), karbohidrat (75,97 $\%)$, timbal $(<0,01 \mathrm{mg} / \mathrm{kg})$, tembaga $(3,43 \mathrm{mg} / \mathrm{kg})$, seng $(17,86 \mathrm{mg} / \mathrm{kg})$, merkuri $(<0,01 \mu \mathrm{g} / \mathrm{kg})$ dan angka cemaran bakteri (ALT) $\left(<25 \times 10^{1} \mathrm{cfu} /\right.$ gram). Selain itu, teh daun kahumama positif mengandung flavanoid, tannin dan steroid.

\section{Pelatihan Manajemen Usaha dan Pemasaran}

Pelatihan manajemen usaha dan pemasaran dilaksanakan di Balai Desa OndoOndolu. Pemateri dalam kegiatan ini yaitu Bapak Haruni Ode, SE.,MM. Kegiatan yang dilaksanakan selama sehari ini selain dihadiri oleh seluruh anggota kelompok tani hutan kahumama, juga mendapatkan perhatian dari kepala desa dan perangkatnya serta warga Desa Ondo-ondolu. Tercatat jumlah peserta yang hadir 30 orang. Dalam kegiatan ini, pemateri menekankan pentingnya manajemen usaha yang baik, senantiasa memperhatikan kreativitas dalam pengemasan produk dan kontinuitas dalam produksi. Untuk pemasaran, pemateri menekankan agar produk yang dihasilkan bisa menyentuh 
seluruh segmentasi masyarakat terutama di daerah. Selain itu perlu menetapkan harga yang ekonomis dan memanfaatkan sebaik mungkin media sosial yang berbasis teknologi informasi agar produk bisa dikenal oleh masyarakat secara umum.

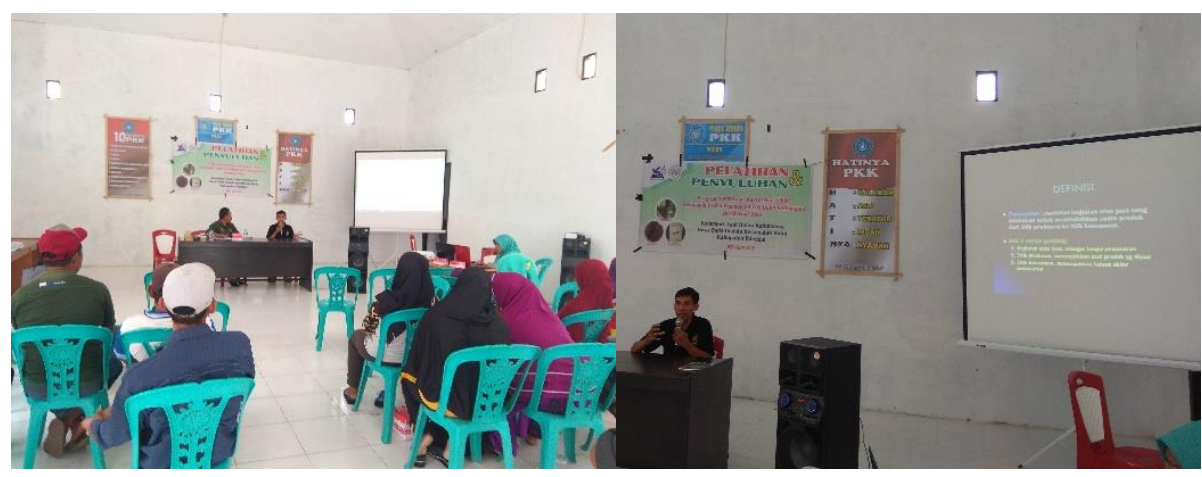

Gambar 2. Pelatihan Manajemen Usaha dan Pemasaran

\section{Penyuluhan Pentingnya Menjaga Hutan}

Penyuluhan pentingnya menjaga hutan di sampaikan langsung oleh kepala kesatuan pengelolaan hutan (KPH) Toili Baturube, Bapak Idrus Habibie, S.Hut. Kegiatan ini dihadiri oleh seluruh anggota KTH Kahumama, perangkat desa, perwakilan mahasiswa dan warga Desa ondo-Ondolu. Dalam pemaparan materinya, kepala KPH menjelaskan kebijakan pemerintah dalam pengelolaan hutan, dampak yang ditimbulkan akibat rusaknya hutan, hasil hutan kayu maupun non kayu serta manfaat hutan dari aspek ekologi, sosial dan ekonomi.

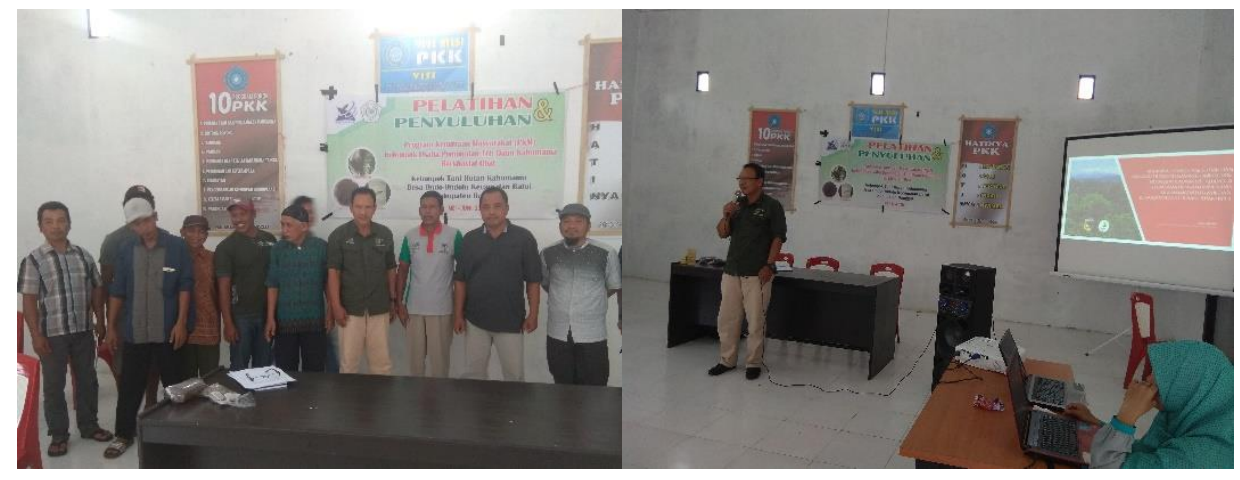

Gambar 3. Penyuluhan tentang Pentingnya Menjaga Hutan

KPH Toili Baturube sangat mendukung pengembangan produk teh daun kahumama yang berkhasiat obat. Harapan Kepala KPH kedepan, terjadi sinergitas antara Perguruan Tinggi Universitas Muhammadiyah Luwuk, kelompok tani hutan dan KPH dalam mengembangkan dan menggali potensi hutan yang ada di wilayah Kabupaten Banggai.

\section{SIMPULAN}

Berdasarkan hasil program kemitraan masyarakat bersama mitra kelompok tani hutan kahumama Desa Ondo-Ondolu Kecamatan Batui Kabupaten Banggai dapat disimpulkan bahwa pengetahuan dan ketrampilan anggota KTH kahumama meningkat 
dalam proses produksi pengolahan teh daun kahumama. Mitra sangat tertarik untuk terus mengolah dan memproduksi teh daun kahumama berkhasiat obat. Selain itu, mitra mulai memahami manajemen, pemasaran produk dan pentingnya menjaga dan memanfaatkan hutan. Namun demikian, masih terdapat kendala dalam akses untuk kelancaran pemasaran produk melalui teknologi informasi seperti media sosial. Dikarenakan masih sangat terbatasnya jangkauan signal telekomunikasi di wilayah kerja mitra.

\section{UCAPAN TERIMA KASIH}

Ucapan terima kasih kepada Direktorat Riset dan Pengabdian Kepada Masyarakat, Direktorat Jenderal Penguatan Riset dan Pengembangan Kementrian Riset, Teknologi dan Pendidikan Tinggi yang telah memberikan dana pengabdian kepada masyaakat melalui skim hibah progam kemitraan masyarakat tahun 2019. Ucapan terima kasih juga kami sampaikan kepada Rektor, Ketua LP3M Universitas Muhammadiyah Luwuk Banggai, KPH Toili Baturube, Masyarakat dan perangkat Desa Ondo-Ondolu yang telah banyak membantu terlaksananya kegiatan ini.

\section{REFERENSI}

Badan Pusat Statistik. (2017). Kabupaten Banggai dalam angka. Banggai: Badan Pusat Statistik Kabupaten Banggai.

Firmansyah, R. (2015). Kewirausahaan dan Strategi Pemasaran. Bandung: Kerjasama: Direktorat Jenderal Industri Kecil \& Menengah, Kementerian Perindustrian Republik Indonesia dan Program Studi Desain Interior, Fak. Industri Kreatif Telkom University.

Fox, J. E. D. (1971). Anthocephalus chinensis, the laran tree of Sabah. Economic Botany, 25(3), 221-233.

Halawane, J. E., Hidayah, H. N., \& Kinho, J. (2011). Prospek pengembangan jabon merah (Anthocephalus macrophyllus (Roxb.)) hasil solusi kebutuhan kayu masa depan. Manado: Balai Penelitian Kehutanan Manado.

Hambali, E., Nasution, M. Z., \& Herliana, E. (2005). Membuat aneka herbal tea. Jakarta: Penebar Swadaya.

Jansen, P. C. M., Westphal, E., Sosef, M. S. M., Soerianegara, I., \& Lemmens, R. H. M. J. (1993). Plant Resources of South-East Asia 5-1. Timber trees: Major commercial timbers. Wageningen, Netherlands: Pudoc Scientific Publishers.

Khodijah S. (2015). Analisis flavonoid total dan aktivitas antioksidan dari berbagai tanaman herbal (Laporan praktik lapangan). Bogor: Institut Pertanian Bogor. 
Krisnawati, H., Kallio, M., \& Kanninen, M. (2011). Anthocepahluus cadamba Miq.: Ecology, Silviculture, and Productivity. Bogor: Center for International Forestry Research (CIFOR).

Lailiyah, N. H. H. (2016). penghambatan akumulasi lipid in vivo pada caenorhabditis elegans oleh ekstrak etanol daun anthocephalus macrophyllus, guazuma ulmifolia, dan melia azedarach. (Skripsi). Bogor: Institut Pertanian Bogor.

Mansur, I., \& Tuhuteru, F.D., (2010). Kayu Jabon. Jakarta: Penebar Swadaya.

Mpapa, B.L. (2016). Jabon merah; Pertumbuhan, sifat kayu dan kegunaannya. Yogyakarta: Plantaxia Graha Ilmu.

Ohorella, S., \& Ladjumat, J. (2009). Kajian keberhasilan program penanaman kayu samama berbasis kearifan lokal masyarakat (Studi Kasus di Desa Tulehu Kabupaten Maluku Tengah). Ambon: Fakultas Pertanian Universitas Darussalam, Ambon.

Orwa, C., Mutua, A., Kindt, R., Jamnadass, R., \& Simons, A., (2009). Agroforestry Tree Database: a Tree Reference and Selection Guide, Version 4.0. Nairobi: World Agroforestry Centre, Kenya.

Supriyanto, S., Darmadji, P., \& Susanti, I. (2014). Studi pembuatan teh daun tanaman kakao (Theobroma cacao L) sebagai minuman penyegar. Agritech, 34(4), 422-429.

Wali, M., Haneda, N. F., \& Maryana, N. (2014). Identification of useful chemical content of red and white jabon leaf (Anthocephalus spp.). Jurnal Silvikultur Tropika, 5(2), 7783. 